\title{
Kesiapan Mahasiswa Kesehatan terhadap Penerapan Pendidikan Interprofesional di Indonesia
}

\author{
Reny Ayu Damayanti ${ }^{*}$, Adang Bachtiar ${ }^{2}$ \\ ${ }^{1,2}$ Universitas Indonesia \\ *Email: reny.ayu81@ui.ac.id
}

\begin{abstract}
Background: Interprofessional education (IPE) is important to create effective interprofessional collaboration also improve quality of health care. Student readiness and perception of IPE will influence the implementation of IPE. This study aimed to analyze an overview, factors that influence and obstacles related to students' readiness and perception of the application of IPE in Indonesia. Methods: Literature reviews with multi-step literature searched on IPE from online databases such as ProQuest; ScienceDirect; SpringerLink and Google scholars by applying the inclusion and exclusion criteria. Samples of 8 studies met the criteria and then analyzed for the study. Results: Most of students have a positive perception and readiness for IPE. Factors influencing students' readiness and perception such as motivation; study program options; student cognitive level; culture; initial clinical experience / exposure; IPE experience in the curriculum; and the readiness of lectures. Conclusion: It is necessary to find a solution in anticipating obstacles in encouraging students' readiness and perception of the application of IPE in Indonesia, including unclear role constraints (role blurring) and the stigma of feeling inferior compared to other health professions.
\end{abstract}

Keywords: interprofessional education (ipe), literature review, readiness, perception

PENDAHULUAN

Profesional kesehatan sebagai pelaku utama penyelenggaran upaya kesehatan dituntut siap menghadapi tantangan dibidang kesehatan (triple burden) yang disebabkan penyakit infeksi, penyakit degeratif serta penyakit emerging seperti covid-19 yang saat ini menjadi pandemi di dunia. Namun kondisi SDM kesehatan global dibayangi krisis seperti kekurangan tenaga, maldistribusi, mismatch, ketidakseimbangan jumlah dan kualitas professional kesehatan, ketidakcocokan antara kompetensi profesional kesehatan dengan kebutuhan penduduk, kerja tim yang buruk serta kepemimpinan yang lemah (Frenk et al., 2010).

World Health Organization (WHO) mengakui kolaborasi interprofesional sebagai sebuah strategi inovatif saat mengatasi krisis profesional kesehatan. Praktiknya, kolaborasi interprofesional bukan tanpa kendala. Belum efektifnya kolaborasi interprofesional dilaporkan masih terjadi di berbagai fasilitas pelayanan kesehatan. Masih adanya komunikasi tidak efektif, stereotyping, serta adanya dominasi salah satu profesi menjadi indikator belum terlaksananya kemitraan yang setara pada profesional kesehatan. Hal ini dapat menyebabkan dampak buruk pada pasien, sehingga perlu segera diatasi. Setiap tahun dilaporkan 2,6 juta kematian akibat rendahnya patient safety dan tingginya angka kesalahan peresepan (medication error) disinyalir akibat buruknya kolaborsi antar profesional kesehatan (Fatalina et al., 2015; Ilmanita \& Rokhman, 2014; Lestari et al., 2016; Notosoegondo \& Bahtera, 2019; WHO, 2010, 2018).

Hasil penelitian Buring et al (2009) dan Groessl \& Vandenhouten (2019) serta Lestari (2011) menunjukkan profesional 
kesehatan yang mendapatkan pendidikan interprofesional (IPE) semasa studinya, akan lebih mudah berkolaborasi dalam setting klinis. Pendidikan interprofesional memungkinkan mahasiswa dari berbagai latar profesi belajar bersama mengenai profesi satu sama lain untuk menciptakan kolaborasi interprofesional yang efektif. Mahasiswa yang memiliki pengalaman praktik bersama dengan latihan IPE memiliki pemahaman yang lebih baik terhadap perspektif disiplin ilmu lain. Mendidik siswa profesi kesehatan dalam lingkungan interprofesional dapat membentuk tim perawatan kesehatan interprofesional yang efektif, sehingga mengurangi kesalahan medis dan meningkatkan hasil pelayanan pasien. Selain itu, IPE dapat meningkatkan kemampuan kepemimpinan dan teamworking serta menumbuhkan pemahaman dan kemampuan partnership mahasiswa (Buring et al., 2009; Groessl \& Vandenhouten, 2019; Lestari, 2011; Oneha et al., 2001; WHO, 2010)

Pendidikan interprofesional sudah diaplikasikan di negara maju seperti Amerika, Kanada, Swedia, dan Australia sejak tahun 1940-an, sebaliknya negara berkembang baru mengaplikasikan IPE mulai tahun 2010-an. Hal ini berpengaruh pada masih terbatasnya diseminasi penelitian terkait IPE di negara berkembang. Penelitian Sunguya (2014) menjelaskan bahwa negara berkembang akan menghadapi lebih banyak tantangan dalam implementasi IPE seperti permasalahan kurikulum, administratif, sarana prasarana, jadwal, dan kesiapan fakultas (Sunguya et al., 2014).

Indonesia memulai penerapan IPE dengan pilot model pembelajaran interprofesional (IPL) dalam perawatan kesehatan berbasis komunitas (CBHC) di
Jakarta tahun 2012 yang diikuti berbagai siswa rumpun kesehatan seperti kedokteran, keperawatan, farmasi, dan kesehatan masyarakat untuk mempromosikan pendidikan interprofesional dan mempresentasikan reaksi siswa akan IPE (Tyastuti et al., 2013).

Dari dimulainya pilot model (2012) sampai sekarang sudah mulai banyak penelitian terkait pendidikan interprofesional di Indonesia terutama dalam mengukur kesiapan siswa dalam penerapan IPE. Kesiapan dan persepsi siswa terkait IPE berpengaruh terhadap penerapan dan keberhasilan IPE. Penelitian ini bertujuan untuk diketahuinya gambaran, faktor yang mempengaruhi serta hambatan terkait kesiapan siswa rumpun ilmu kesehatan terhadap penerapan IPE di Indonesia. Penelitian terkait kesiapan siswa terhadap implementasi IPE di Indonesia penting dilakukan karena sebagai evidence based yang akan memberi masukan peningkatan efektivitas penerapan IPE yang sesuai dengan budaya di Indonesia, tidak hanya berdasar asumsi dan peralatan yang serupa yang digunakan di negara maju.

\section{METODE PENELITIAN}

Studi ini merupakan literature review yang dilakukan dengan mencari artikel dari 4 online basis data yaitu ProQuest, Science Direct, Springer Link, dan Google Cendekia untuk mencari artikel yang relevan dengan tujuan penelitian. Pencarian artikel menggunakan 4 tahap.

Tahap pertama adalah pencarian literature terkait Interprofesional Education (IPE) dengan menggunakan kombinasi kata kunci sebagai berikut: ((IPE OR "Interprofessional education") 
AND (Perception OR Readiness)) AND Indonesia. Pada tahap pertama pencarian, diperoleh 585 artikel. Pada tahap kedua peneliti mereduksi data dengan membaca judul dan abstrak. Pada tahap ini penyaringan artikel dengan menerapkan kriteria inklusi penelitian sebagai berikut : penelitian tentang readiness atau persepsi kesiapan siswa kesehatan terhadap implementasi IPE, penelitian dilakukan di wilayah Republik Indonesia, rentang tahun penelitian sepuluh tahun terakhir (2010-2020), artikel dengan akses terbuka, dan full paper. Peneliti memperoleh 94 artikel yang sesuai.

Tahap ketiga yaitu peneliti membaca dan mencermati isi full paper untuk menilai artikel secara komprehensif. Artikel yang dipilih adalah yang mempunyai relevansi dengan kriteria inklusi dan berhubungan dengan topik pendidikan interprofesional. Hasil penilaian kritis didapatkan 46 artikel.

Tahap terakhir menerapkan kriteria eksklusi yaitu artikel membahas mengenai Interprofessional Collaboration (IPC), artikel mengenai Pengalaman Belajar Lapangan (PBL), membahas Interprofessional Learning (IPL), artikel selain dari jurnal atau prosiding, dan duplikasi maka tidak diikutsertakan. Peneliti mengeluarkan artikel yang tidak relevan dan duplikasi, sehingga didapatkan 8 artikel dipilih untuk diproses lebih lanjut. Gambaran umum proses identifikasi, penyaringan, penentuan kelayakan, dan penyertaan artikel yang digunakan dalam literature review ini diilustrasikan dalam Gambar 1.

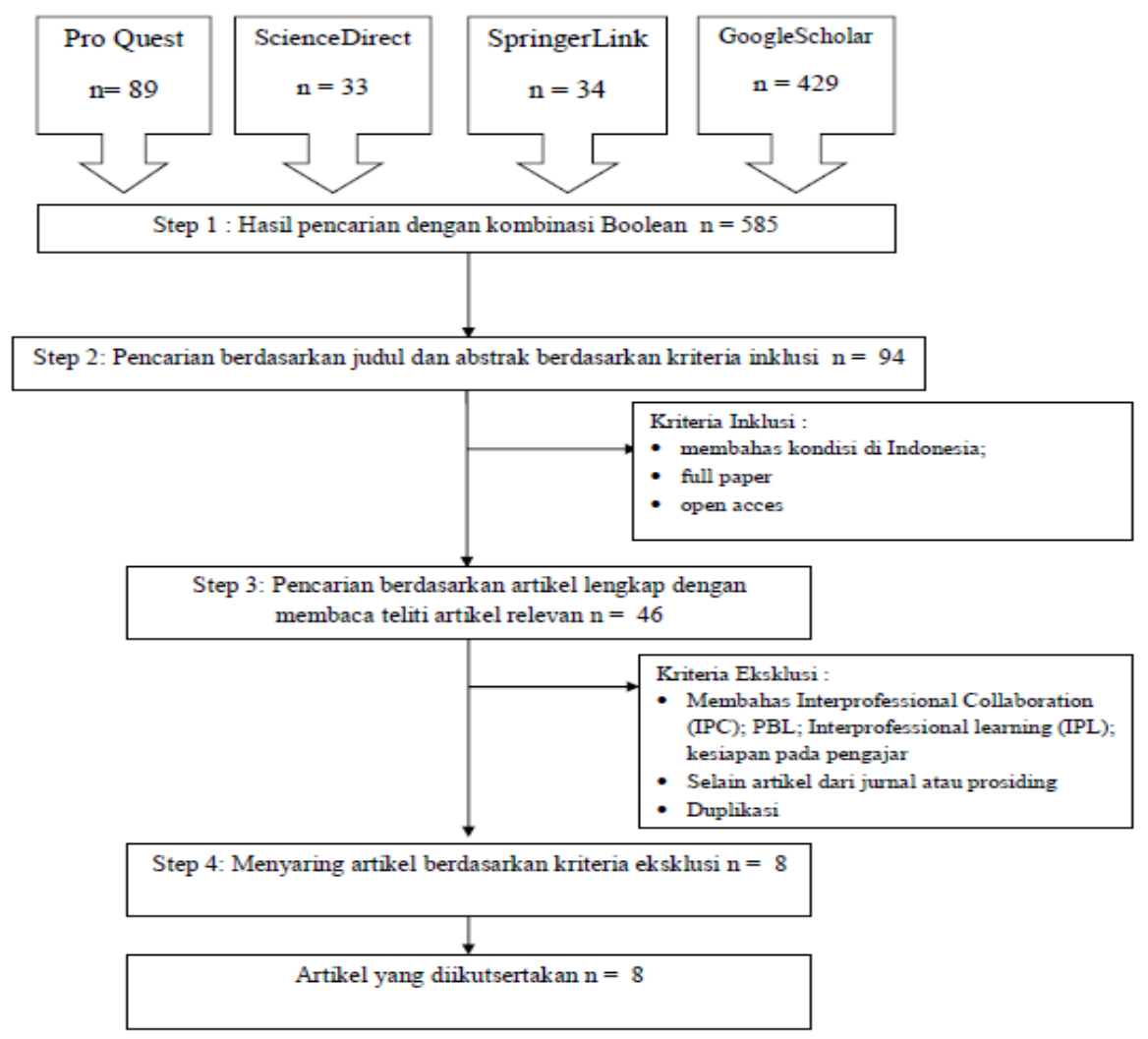

Gambar 1. Alur proses pencarian 


\section{HASIL PENELITIAN}

\section{Gambaran Implementasi IPE}

Hasil literature review menunjukkan bahwa penelitian yang membahas mengenai kesiapan dan persepsi mahasiswa terkait penerapan pendidikan interprofesional di Indonesia cukup banyak dilakukan diberbagai Universitas di Indonesia. Sesuai 8 artikel yang memenuhi kriteria eligibility, penelitian berfokus melihat gambaran kesiapan dan persepsi mahasiswa dalam penerapan IPE.

Metode penelitian yang digunakan pada artikel-artikel tersebut adalah metode cross-sectional survey, mixed method, dan quasi eksperimental. Studi kuasi eksperimen dilakukan dengan memberikan pelatihan yang secara signifikan meningkatkan nilai persepsi siswa atau mahasiswa terhadap IPE. Sedang cross-sectional survey dilaksanakan dengan melakukan pengukuran kesiapan siswa menggunakan kuesioner Readiness for InterProfessional Learning Scale (RIPLS) dan untuk mengukur variabel persepsi digunakan kuesioner Scale of Attitudes Toward Physician-Pharmacist Collaboration (SATP2C), Interdisciplinary Education Perception Scale (IEPS), Teamwork Score (TWS), dan Student Perceptions of PhysicianPharmacist Interprofessional Clinical Education (SPICE). Pada metode mixed setelah dilakukan analisis kuesioner dilanjutkan dengan pendekatan kualiatif berupa diskusi grup terarah.

\section{Implementasi IPE}

Implementasi IPE di masing-masing perguruan tinggi bervariasi. Dari hasil penelusuran belum ada satupun perguruan tinggi yang telah menerapkan IPE masuk ke dalam level kurikulum. Perguruan tinggi hanya menerapkan IPE sebagai model dalam pembelajaran (Dewi et al., 2019; Febriana et al., 2019; Ilmanita \& Rokhman, 2014). Peneliti menemukan satu institusi sedang dalam proses mengembangkan kurikulum IPE untuk program medis dan kesehatan lainnya (Lestari et al., 2016) dan sisanya belum mengimplementasikan IPE sama sekali (Fuadah et al., 2012; Haryati et al., 2019; Rasmita, Dina (Unpri et al., 2018; Setyo et al., 2018).

\section{Gambaran Kesiapan dan Persepsi Mahasiswa}

Dari seluruh artikel menyatakan bahwa persepsi dan kesiapan siswa kesehatan terhadap IPE adalah positif. Baik pada institusi yang sudah menerapkan kurikulum pembelajaran IPE maupun tidak. Para siswa memahami bahwa program IPE ini memberi mereka pemahaman tentang kemampuan, kemandirian, keinginan untuk kolaborasi dalam aksi nyata, serta mendalami peran profesi lain (Dewi et al., 2019).

Nilai kuantitatif mahasiswa kedokteran menunjukkan nilai kesiapan paling tinggi diantara siswa kesehatan lainnya (Dewi et al., 2019; Lestari et al., 2016). Mengenai semua subskala IEPS, mahasiswa kedokteran memiliki skor tertinggi kecuali pada subskala kerja sama. Sehubungan dengan subskala peran dan tanggung jawab, mahasiswa kedokteran memiliki skor terendah (Dewi et al., 2019).

Pada penelitian quasi eksperimen dengan memberikan intervensi berupa pelatihan kepada mahasiswa kemudian dibandingkan nilai rata-rata sebelum dan sesudah intervensi menghasilkan perubahan signifikan berupa peningkatan nilai rata-rata. Hasil tersebut menunjukkan 
bahwa sikap mahasiswa setelah diberi pelatihan terhadap pembelajaran interprofesional jadi lebih positif (Fuadah et al., 2012; Setyo et al., 2018).

Hasil penelitian Ilmanita \& Rokhman (2014) yaitu nilai kuantitatif antara mahasiswa yang telah terpapar IPE memiliki rata-rata skor RIPLS lebih tinggi

Tabel 1. Berdasarkan analisis literatur yang telah dilakukan pada seluruh artikel terpilih, menunjukkan bahwa penerapan interprofessional education (IPE) bertujuan penting dalam pembelajaran keterampilan komunikasi dan kepemimpinan (Lestari et al., 2016), kerjasama dan identitas profesi (Fuadah et al., 2012; Rasmita, Dina (Unpri et al., 2018), kolaborasi antar profesi (Fuadah et al., 2012; Ilmanita \& Rokhman, 2014), tingkat percaya diri (Ilmanita \& Rokhman, 2014), kompetensi dan otonomi, kebutuhan akan kolaborasi, bukti kolaborasi dan pemahaman tentang profesi lain (Febriana et al., 2019; Setyo et al., 2018).

\section{PEMBAHASAN}

\section{Kesiapan Mahasiswa dalam Implementasi IPE}

Kesiapan mahasiswa memberikan dampak yang besar dalam implementasi pembelajaran secara interprofesional. Riwayat IPE pada siswa akan mendorong timbulnya kesiapan dalam melaksanakan kolaborasi interprofesional daripada siswa yang sama sekali tidak pernah menerima informasi terkait IPE sebelumnya (Fuadah et al., 2012). Fuadah et al (2012) menyatakan cara yang cukup ampuh dalam mempersiapkan kesiapan siswa melaksanakan pendidikan interprofesional adalah dengan jalan pemberian pengetahuan dan pengalaman bekerja dibanding yang belum pernah mengikuti IPE pada sub skala tanggung jawab (Ilmanita \& Rokhman, 2014).

\section{Tujuan penerapan IPE}

Hasil rangkuman artikel seperti tercantum pada

bersama dalam setting interprofesional melalui pelatihan.

Nilai kuantitatif kesiapan mahasiswa kedokteran memiliki paling tinggi, hal ini mungkin disebabkan saat pendaftaran mengharuskan mahasiswa kedokteran untuk memiliki nilai kelulusan tertinggi dibandingkan dengan siswa lain (Dewi et al., 2019). Hal ini senada dengan hasil penelitian Lestari (2016) bahwa siswa dengan kemampuan kognitif tinggi berpotensi lebih siap untuk belajar dengan siswa disiplin ilmu yang lain di IPE. Hasil penelitian tersebut menjelaskan bahwa program studi yang dipilih, IPK, motivasi dan pengalaman bekerja dengan siswa dari program studi lain adalah faktor yang secara signifikan mempengaruhi total skor kuesioner RIPLS untuk mengukur kesiapan siswa menerima implementasi IPE.

\section{Persepsi Mahasiswa dalam Implementasi IPE}

IPE memiliki potensi untuk secara positif mempengaruhi sikap dan persepsi siswa terhadap kolaborasi antarprofesional dan meningkatkan efektivitas pengambilan keputusan klinis dan kualitas perawatan (Anwar \& Rosa, 2019). Persepsi positif dapat menjadi modal awal yang baik mahasiswa untuk mengikuti tahap pembelajaran akademik. Karena persepsi sangat berpengaruh pada motivasi mahasiswa entah untuk belajar (Febriana et al., 2019). Kemajuan 
dinamika kelompok dan hubungan pribadi selama upaya diskusi mungkin sangat memengaruhi pembentukan persepsi positif ketika IPE diperkenalkan secara bertahap (Setyo et al., 2018).

Beberapa metode

telah dikembangkan untuk meningkatkan persepsi mahasiswa terkait IPE. Metode simulasi menurut Setyo (2018) selain tidak hanya memperkenalkan IPE tetapi juga meningkatkan kepercayaan diri, pengetahuan, kepemimpinan, kerja tim, serta keterampilan komunikasi. Studi tahun 2015 oleh Ernawati menemukan bahwa belajar dengan mahasiswa kesehatan lainnya melalui lokakarya IPE meningkatkan sikap mahasiswa kedokteran, keperawatan dan farmasi terhadap pentingnya pembelajaran bersama, kerja tim, dan komunikasi dalam layanan kesehatan (Ernawati, 2015).

IPE selama masa pendidikan memainkan peran dalam membentuk persepsi positif IPE, siswa senior lebih cenderung memiliki sikap positif terhadap pembelajaran interprofesional daripada siswa junior (Haryati et al., 2019).

\section{Faktor-faktor yang Mempengaruhi} Implementasi IPE

Analisis dari berbagai artikel disimpulkan berbagai faktor yang mempengaruhi kesiapan dan persepsi mahasiswa dalam implementasi IPE antara lain : motivasi serta pilihan program studi (Lestari et al., 2016), tingkat kognitif mahasiswa, paparan klinis awal pada mahasiswa dan pengalaman IPE dalam kurikulum (Dewi et al., 2019; Lestari et al., 2016), serta budaya tertentu (Dewi et al., 2019; Setyo et al., 2018).

Hal ini sejalan dengan hasil penelitian Lestari (2018) bahwa terdapat faktor yang mempengaruhi kesiapan dan sikap profesional kesehatan terhadap penerapan IPE antara lain tergantung pada latar belakang profesi, latar belakang pendidikan, gelar akademis, lama bekerja, latar belakang kelembagaan, dan pendekatan pengajaran yang digunakan di sekolah terkait dengan sikap terhadap IPC dan IPE. Faktor dari institusi (fakultas dan pendidik) juga memperikan pengaruh terhadap kesiapan dan persepsi mahasiswa dalam implementasi IPE. Peran institusi pendidikan dalam mempersiapkan implementasi IPE antara lain penyiapan sarana prasarana (ruang pembelaaajaran; sistem pembelajaran; kurikulum terkait interprofesional) dan juga perlu mempersipkan anggaran agar program IPE terlaksana dengan efektif (Rasmita, Dina (Unpri et al., 2018; Vrontos et al., 2011).

Untuk menciptakan kesiapan dan persepsi positif maka kegiatan interprofesi dalam setting klinis dengan pemberian studi kasus untuk dipecahkan bersama oleh siswa dari berbagai latar profesi harus dilaksanakan secara berkesinambungan dan perlu dimasukkan ke dalam kurikulum pendidikan (Fuadah et al., 2012). Dewi (2019) juga menyatakan bahwa faktor yang tidak diinginkan dapat diminimalkan dengan mengembangkan IPE dalam kurikulum perawatan kesehatan sedini mungkin untuk meningkatkan sikap siswa terhadap IPE. Hal ini juga senada dengan saran dari Lestari (2016) bahwa implementasi perlu masuk ke dalam kurikulum.

Dosen maupun staff mengajar menjadi salah satu faktor pembentuk kesiapan mahasiswa dalam penerapan IPE. Tenaga pendidik memiliki peran yang krusial sebagai role model, peran ini penting untuk mengklarifikasi dan memahami profesi dan batas peran profesi 
masing-masing sewaktu memberikan bimbingan pada siswa dalam simulasi kasus (Fuadah et al., 2012). Maka dituntut lagi peran institusi dengan meningkatan kompetensi SDM pendidik agar menguasai konteks pendidikan interprofesional misalnya dengan memberikan pelatihan terkait IPE (Lestari et al., 2018).

\section{Hubungan antara Persepsi dengan Kesiapan Penerapan IPE pada Mahasiswa}

Penerapan IPE memiliki berbagai tujuan salah satunya timbulnya praktik kolaborasi dan kerjasama antar latar belakang profesi untuk bekerja bersamasama menghasilkan pelayanan kesehatan yang bermutu.

Kesiapan dan persepsi mahasiswa terhadap IPE akan berpengaruh terhadap pelaksanaan kerja bersama/kolaborasi baik di level akademik maupun di layanan kesehatan nantinya. Persepsi seseorang tentang implementasi IPE kadang mempengaruhi kesiapan mahasiswa dalam mengikuti kegiatan IPE. Persepsi awal yang positif akan membuat mahasiswa merasa lebih siap terlibat dalam kegiatan atau pelaksanaan IPE. Outcome yang diharapkan akan menghasilkan kolaborasi antarprofesi yang baik.

Demikian pula sebaliknya persepsi negatif akan mengurangi antusiasme mahasiswa dalam mengikuti IPE. Seperti hasil penelitian Lestari (2016) yang menyatakan bahwa ada kepercayaan yang diyakini secara luas bahwa dokter memiliki peringkat lebih tinggi dalam status dibandingkan dengan profesional kesehatan lainnya. Kondisi ini membawa persepsi negative bagi beberapa mahasiswa profesi lain, yang melemahkan kepercayaan mereka pada keuntungan IPE. Akibat kondisi tersebut maka antusiasme mahasiswa non kedokteran dalam mengimplementasikan IPE mengalami penurunan.

Tabel 1. Studi Literatur

\begin{tabular}{|c|c|c|c|c|c|c|}
\hline No & Author & Judul & Th & $\begin{array}{c}\text { Design } \\
\& \\
\text { Metode }\end{array}$ & Tujuan & Hasil \\
\hline 1 . & $\begin{array}{l}\text { Lestari } \\
\text { et al. }\end{array}$ & $\begin{array}{l}\text { Understanding } \\
\text { students } \\
\text { readiness for } \\
\text { interprofessiona } \\
\text { l learning in an } \\
\text { Asian context: a } \\
\text { mixed-methods } \\
\text { study }\end{array}$ & 2016 & $\begin{array}{l}\text { Mixed } \\
\text { method }\end{array}$ & $\begin{array}{l}\text { Untuk mengetahui } \\
\text { kesiapan siswa untuk } \\
\text { IPE dalam konteks } \\
\text { Asia, faktor paling } \\
\text { penting yang } \\
\text { mempengaruhi persepsi } \\
\text { siswa tentang IPE, } \\
\text { alasan yang mendasari } \\
\text { persepsi tersebut, dan } \\
\text { faktor yang memitigasi } \\
\text { atau meningkatkan rasa } \\
\text { kesiapan mereka. }\end{array}$ & 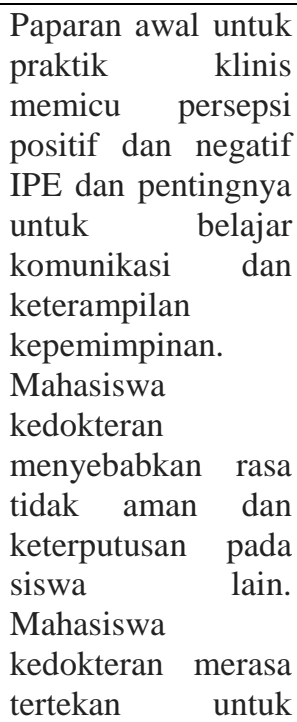 \\
\hline
\end{tabular}




\begin{tabular}{|c|c|c|c|c|c|c|}
\hline & & & & & & $\begin{array}{l}\text { menjadi pemimpin, } \\
\text { dan ada kebutuhan } \\
\text { untuk } \\
\text { mengklarifikasi dan } \\
\text { memahami profesi } \\
\text { masing-masing dan } \\
\text { batas-batas profesi } \\
\text { masing-masing. }\end{array}$ \\
\hline 2. & $\begin{array}{l}\text { Dewi et } \\
\text { al. }\end{array}$ & $\begin{array}{l}\text { Undergraduate } \\
\text { Students' Percep } \\
\text { tions and Readi } \\
\text { ness: An } \\
\text { Evaluation of } \\
\text { Inter- } \\
\text { Professional } \\
\text { Education at } \\
\text { Central } \\
\text { Java, Indonesia }\end{array}$ & 2019 & $\begin{array}{l}\text { Cross- } \\
\text { sectiona } \\
\text { l survey }\end{array}$ & $\begin{array}{l}\text { Diketahui gambaran } \\
\text { persepsi dan kesiapan } \\
\text { untuk IPE di kalangan } \\
\text { mahasiswa } \\
\text { keperawatan, medis dan } \\
\text { farmasi }\end{array}$ & $\begin{array}{l}\text { Para siswa memiliki } \\
\text { persepsi positif dan } \\
\text { kesiapan terhadap } \\
\text { program IPE. Ini } \\
\text { mungkin karena } \\
\text { kemampuan } \\
\text { kognitif, } \\
\text { budaya, sosialisasi, } \\
\text { pengalaman klinis } \\
\text { awal dan paparan } \\
\text { IPE dalam } \\
\text { kurikulum. }\end{array}$ \\
\hline 3. & $\begin{array}{l}\text { Haryati } \\
\text { et al. }\end{array}$ & $\begin{array}{l}\text { Perception of } \\
\text { Medical Faculty } \\
\text { Student of } \\
\text { Haluoleo } \\
\text { University about } \\
\text { Inter } \\
\text { Professional } \\
\text { Education }\end{array}$ & 2019 & $\begin{array}{l}\text { Cross- } \\
\text { sectiona } \\
\text { l survey }\end{array}$ & $\begin{array}{l}\text { Diidentifikasikannya } \\
\text { persepsi mahasiswa } \\
\text { kedokteran tentang } \\
\text { pendidikan } \\
\text { interprofesional di } \\
\text { fakultas kedokteran } \\
\text { Universitas Halu Oleo }\end{array}$ & $\begin{array}{lr}\text { Tidak } & \text { ada } \\
\text { perbedaan persepsi } \\
\text { antara mahasiswa } \\
\text { Kedokteran } & \\
\text { Universitas } & \text { Halu } \\
\text { Oleo tentang } & \text { IPE } \\
\text { baik siswa } & \text { di } \\
\text { Program } & \text { Studi } \\
\text { Pendidikan } & \\
\text { Kedokteran } & \text { dan } \\
\text { siswa } & \text { dalam } \\
\text { Konsentrasi } & \\
\text { Keperawatan } & \end{array}$ \\
\hline 4. & $\begin{array}{l}\text { Setyo et } \\
\text { al. }\end{array}$ & $\begin{array}{l}\text { Improvement } \\
\text { In Perception O } \\
f \\
\text { Interprofessiona } \\
\text { l Team After } \\
\text { Receiving IPE T } \\
\text { raining On } \\
\text { Unified } \\
\text { Collaborative } \\
\text { Care For } \\
\text { Diarrhea In } \\
\text { Children Among } \\
\text { Students Of } \\
\text { Mahardika } \\
\text { Health College }\end{array}$ & 2018 & $\begin{array}{l}\text { Quasi } \\
\text { experim } \\
\text { ent }\end{array}$ & $\begin{array}{l}\text { Diketahuinya pengaruh } \\
\text { pelatihan IPE dalam } \\
\text { perawatan kolaboratif } \\
\text { terpadu untuk diare } \\
\text { pada anak-anak pada } \\
\text { persepsi siswa dalam } \\
\text { tim multi-profesi }\end{array}$ & $\begin{array}{l}\text { Terdapat perbedaan } \\
\text { signifikan dalam } \\
\text { persepsi siswa } \\
\text { setelah diberikan } \\
\text { perawatan. Studi ini } \\
\text { menyimpulkan } \\
\text { bahwa pelatihan } \\
\text { IPE meningkatkan } \\
\text { persepsi siswa } \\
\text { untuk bekerja di } \\
\text { lingkungan multi- } \\
\text { profesi }\end{array}$ \\
\hline 5. & $\begin{array}{l}\text { Rasmita } \\
\text { et al. }\end{array}$ & $\begin{array}{l}\text { Gambaran } \\
\text { Persepsi Dan } \\
\text { Kesiapan } \\
\text { Mahasiswa } \\
\text { Terhadap }\end{array}$ & 2018 & $\begin{array}{l}\text { Mixed } \\
\text { method }\end{array}$ & $\begin{array}{lr}\text { Diketahui } & \text { gambaran } \\
\text { kesiapan dan persepsi } \\
\text { siswa dalam } \\
\text { implementasi IPE }\end{array}$ & $\begin{array}{l}\text { Sebagian besar } \\
\text { mahasiswa } \\
\text { memiliki persepsi } \\
\text { yang positif }(60 \%) \\
\text { dan memiliki }\end{array}$ \\
\hline
\end{tabular}




\begin{tabular}{|c|c|c|c|c|c|c|}
\hline & & $\begin{array}{l}\text { Implementasi } \\
\text { Ipe } \\
\text { (Interprofession } \\
\text { al Education) Di } \\
\text { Stikes Surya } \\
\text { Global } \\
\text { Yogyakarta }\end{array}$ & & & & $\begin{array}{lr}\text { kesiapan } & \text { yang baik } \\
(83 \%), & \text { diperkuat } \\
\text { hasil } & \text { analisis } \\
\text { kualitatif } & \text { yang } \\
\text { menyatakan } & \text { hal } \\
\text { yang sama. } & \end{array}$ \\
\hline 6. & $\begin{array}{l}\text { Fuadah } \\
\text { et al. }\end{array}$ & $\begin{array}{l}\text { Kesiapan } \\
\text { Mahasiswa } \\
\text { Untuk Belajar } \\
\text { Kerjasama } \\
\text { Interprofesi } \\
\text { Dalam } \\
\text { Perawatan } \\
\text { Antenatal }\end{array}$ & 2012 & $\begin{array}{l}\text { Quasi } \\
\text { experim } \\
\text { ent }\end{array}$ & $\begin{array}{l}\text { Diketahuinya peran IPE } \\
\text { terhadap kesiapan } \\
\text { siswa dalam bekerja } \\
\text { secara interprofesional } \\
\text { dalam setting } \\
\text { perawatan antenatal }\end{array}$ & $\begin{array}{l}\text { Terdapat perbedaan } \\
\text { signifikan dalam } \\
\text { skor kesiapan siswa } \\
\text { yang diukur } \\
\text { sebelum dan setelah } \\
\text { diberikan pelatihan } \\
\text { pendidikan } \\
\text { interprofesional. }\end{array}$ \\
\hline 7. & $\begin{array}{l}\text { Ilmanita } \\
\text { et al. }\end{array}$ & $\begin{array}{l}\text { Peran } \\
\text { Interprofessiona } \\
\text { 1 Education } \\
\text { Terhadap } \\
\text { Persepsi } \\
\text { Keterlibatan } \\
\text { Apoteker Dalam } \\
\text { Kolaborasi } \\
\text { Antar Profesi }\end{array}$ & 2014 & $\begin{array}{l}\text { Cross- } \\
\text { sectiona } \\
\text { l survey }\end{array}$ & $\begin{array}{l}\text { Diketahui pengaruh } \\
\text { pendidikan } \\
\text { interprofesional } \\
\text { terhadap persepsi siswa } \\
\text { kaitannya dengan } \\
\text { kolaborasi antara } \\
\text { profesi apoteker dengan } \\
\text { profesi lainnya }\end{array}$ & $\begin{array}{lr}\text { Siswa yang } & \text { telah } \\
\text { terpapar } & \text { IPE } \\
\text { memiliki persepsi } & \text { yang lebih positif } \\
\text { dalam subskala } & \text { sum } \\
\text { interprofesional } \\
(84,6 \%) \text { dibanding } \\
\text { yang r belum } \\
\text { memiliki riwayat } \\
\text { IPE. }\end{array}$ \\
\hline 8 . & Febriana & $\begin{array}{l}\text { Kesiapan Dan } \\
\text { Persepsi } \\
\text { Mahasiswa } \\
\text { Keperawatan } \\
\text { Pada Program } \\
\text { Ipe : Studi Pada } \\
\text { SGD dengan } \\
\text { LBM Jiwa }\end{array}$ & 2019 & $\begin{array}{l}\text { Cross- } \\
\text { sectiona } \\
\text { l survey }\end{array}$ & $\begin{array}{lr}\text { Diketahui } & \text { gambaran } \\
\text { persepsi } & \text { mahasiswa } \\
\text { tentang } & \text { metode } \\
\text { pembelajaan } & \text { IPE dan } \\
\text { kesiapan } & \text { mereka } \\
\text { menghadapinya }\end{array}$ & $\begin{array}{l}\text { Sebagian besar } \\
\text { mahasiswa } \\
\text { keperawatan } \\
\text { memiliki persepsi } \\
(84 \%) \text { dan kesiapan } \\
(85 \%) \text { yang baik, } \\
\text { hal ini } \\
\text { menunjukkan siswa } \\
\text { siap } \\
\text { mengaplikasikan } \\
\text { IPE dalam tahap } \\
\text { akademik. }\end{array}$ \\
\hline
\end{tabular}

\section{Hambatan dalam Implementasi IPE}

Mahasiswa Indonesia umumnya menghargai manfaat IPE dalam mengasah keterampilan kepemimpinan, kolaborasi, komunikasi antar profesional, dan dalam pembelajaran mereka untuk mengatasi masalah peran yang ambigu (Lestari et al., 2016). Dengan memperkenalkan IPE dilakukan sedini mungkin, diharapkan dapat mencegah hambatan yang muncul yaitu stereotip negatif yang dapat menghambat komunikasi antar tenaga kesehatan (Rasmita, Dina (Unpri et al., 2018).

Temuan menarik pada penelitian Lestari (2016) dalam pelaksanaan IPE mengemuka sebuah statement "Medical students caused insecurity and disengagement in other students" yang artinya mahasiswa kedokteran membuat rasa tidak nyaman, kekhawatiran pada mahasiswa (profesi) lain. Hal ini senada 
pula dengan hasil penelitian Dewi (2019) "People perceive and believe that medical doctors or medical students are more prestigious than other health professions" bahwa di masyarakat luas mempercayai bahwa tenaga medis/dokter lebih prestisiun dibandingkan tenaga kesehatan lain. Hal ini dapat menjadi hambatan dalam pelaksanaan Interprofessional Education dan Interprofessional collaboration kelak.

Dalam budaya Indonesia, khususnya Jawa, orang memandang dan percaya bahwa dokter atau mahasiswa kedokteran lebih bergengsi daripada profesi kesehatan lainnya (Dewi et al., 2019), hal ini dapat mengakibatkan kecemasan pada mahasiswa keperawatan yang akan merusak kepercayaan mereka pada IPE. Pelajar keperawatan berpikir bahwa mereka hanya membantu dokter dalam mengelola pasien (Lestari et al., 2016). Mahasiswa kedoteran juga memberi kesan mempertahankan 'eksklusivitas kognitif' mereka terhadap praktik perawatan kesehatan Kondisi ini dapat berisiko ketidakamanan pasien karena seorang profesional tertentu merasa lebih unggul daripada yang lain.

Setiap tenaga kesehatan memiliki peran dan kompetensi yang berbeda-beda. Batas peran yang tidak jelas antara profesional kesehatan mempersulit kolaborasi interprofesional di Indonesia dan merupakan alasan tambahan bagi beberapa siswa untuk memiliki persepsi negatif tentang IPE (Lestari et al., 2016). Memahami peran dan wewenang setiap profesi kesehatan adalah faktor penting untuk kerja tim yang efektif (Findyartini et al., 2019).

Lestari (2016) menyatakan untuk mengatasi bauran peran antar profesi diperlukan role model yang kuat dari berbagai profesi kesehatan untuk membantu menciptakan dan mengimplementasikan program IPE yang sukses dan pada akhirnya meningkatkan kolaborasi antarprofesional dalam sistem perawatan kesehatan Indonesia.

\section{KESIMPULAN DAN SARAN}

Hasil penelusuran artikel yang terbit dalam rentang tahun 2010-2020, yang dilaksanakan dengan metode crosssectional survey; mixed method; dan quasi eksperimental di wilayah Jawa Tengah; Yogyakarta; Jawa Barat; Sulawesi Tenggara; Jawa Timur; maka dapat disimpulkan bahwa mayoritas mahasiswa memiliki persepsi dan kesiapan positif terhadap penerapan pendidikan interprofesional di Indonesia. Baik pada institusi yang sudah menerapkan kurikulum pembelajaran IPE maupun tidak.

Berdasarkan analisis artikel yang digunakan sebagai literatur menunjukkan bahwa faktor yang mempengaruhi kesiapan dan persepsi siswa terhadap penerapan IPE di Indonesia antara lain motivasi, pilihan program studi, tingkat kognitif mahasiswa, budaya, pengalaman/paparan klinis awal, pengalaman IPE dalam kurikulum, dan kesiapan tenaga pendidik. Selain itu institusi perlu menyiapkan sarana, prasarana serta kurikulum terkait penerapan IPE.

Masih terdapat hambatan dalam mendorong kesiapan dan persepsi siswa terhadap penerapan IPE di Indonesia antara lain batasan peran yang belum jelas dan stigma merasa inferior dibanding profesi kesehatan lain.

Institusi pendidikan kesehatan harus mulai memasukkan program IPE yang memfasilitasi pembelajaran kolaboratif 
bagi seluruh mahasiswa multidisiplin ke dalam kurikulum, yang didalamnya mengakomodir penjelasan pembagian yang jelas atas peran profesi kesehatan masing-masing sehingga kebingungan mahasiswa akan peran profesi kesehatan dapat dihilangkan. Semakin awal implementasi IPE akan meningkatkan kesiapan dan persepsi positif mahasiswa.

\section{DAFTAR RUJUKAN}

Anwar, H., \& Rosa, E. M. (2019). Meningkatkan Komunikasi dan Kolaborasi dengan Interprofessional Education (IPE): Literature Review. Jurnal Keperawatan Muhammadiyah Alamat, 91-101.

Buring, S. M., Bhushan, A., Brazeau, G., Conway, S., Hansen, L., \& Westberg, S. (2009). Keys to successful implementation of interprofessional education: Learning location, faculty development, and curricular themes. American Journal of Pharmaceutical Education, 73(4). https://doi.org/10.5688/aj730460

Dewi, E., Pratiwi, A., \& Soh, K. L. (2019). Undergraduate Students Perceptions and Readiness: An Evaluation of Inter-Professional Education at Central Java , Indonesia. 18(11), 193-204.

Ernawati, D. K. (2015). Medication safety in Indonesia: Expanding pharmacists' role through Interprofessional Education (IPE) and Interprofessional Practice (IPP). July.

Fatalina, F., Sunartini, S., Widyandana,
W., \& Sedyowinarso, M. (2015). Persepsi Dan Penerimaan Interprofessional Collaborative Practice Bidang Maternitas Pada Tenaga Kesehatan. Jurnal Pendidikan Kedokteran Indonesia, 4(1), 1.

Febriana, B., Keperawatan, F. I., Islam, U., \& Agung, S. (2019). Kesiapan Dan Persepsi Mahasiswa Keperawatan Pada Program Ipe Models: Studi Pada Sgd Dengan Lbm Jiwa. Jurnal Keperawatan Jiwa, 7(1), 101-106.

Findyartini, A., Richard, D., Yeti, R., Boy, A., Dini, C., Setyorini, D., \& Soemantri, D. (2019). Journal of Interprofessional Education \& Practice Interprofessional collaborative practice in primary healthcare settings in Indonesia: A mixed-methods study. Journal of Interprofessional Education \& Practice, 17 (July), 100279. https://doi.org/10.1016/j.xjep.2019.1 00279

Frenk, J., Chen, L., Bhutta, Z. A., Cohen, J., Crisp, N., Evans, T., Fineberg, H., Garcia, P., Ke, Y., Kelley, P., Kistnasamy, B., Meleis, A., Naylor, D., Pablos-Mendez, A., Reddy, S., Scrimshaw, S., Sepulveda, J., Serwadda, D., \& Zurayk, H. (2010). Health professionals for a new century: Ttransforming education to strengthen health systems in an interdependent world. The Lancet, 376(9756), 1923-1958. https://doi.org/10.1016/S01406736(10)61854-5 
Fuadah, D. Z., Hapsara, S., \& Sedyowinarso, M. (2012). Kesiapan mahasiswa untuk belajar kerjasama interprofesi dalam perawatan antenatal. Jurnal Ners, 9 No.2(Oktober 2014), 226-235.

Groessl, J. M., \& Vandenhouten, C. L. (2019). Examining Students Attitudes and Readiness for Interprofessional Education and Practice.2019.https://doi.org/10.115 5/2019/2153292

Haryati, H., Ashaeryanto, A., Rangki, L., \& Sardila, E. (2019). Perception of Medical Faculty Student of Haluoleo University about Inter Professional Education. ICEASD 2019, April 01-02, Indonesia Copyright.https://doi.org/10.4108/ea i.1-4-2019.2287178

Ilmanita, D., \& Rokhman, R. (2014). Peran Interprofessional Education Terhadap Persepsi Keterlibatan Apoteker Dalam Kolaborasi Antar Profesi. Jurnal Manajemen Dan Pelayanan Farmasi, 4(September), 166-174.

Lestari, E. (2011). Menumbuhkan Ketrampilan Kepemimpinan dan Team- Building serta Penghargaan terhadap Profesi Lain Melalui Interprofessional Education. Multiprofesional Learning, 3(1), 89-101.

Lestari, E., Stalmeijer, R. E., Widyandana, D., \& Scherpbier, A. (2016). Understanding students ' readiness for interprofessional learning in an Asian context : a mixed-methods study. $1-12$. https://doi.org/10.1186/s12909-0160704-3

Lestari, E., Widyandana, D., \& Scherpbier, A. (2018). Understanding attitude of health care professional teachers toward interprofessional health care collaboration and education in a Southeast Asian country.

Notosoegondo, H. S., \& Bahtera, T. (2019). The Journal of Educational Development Development of Patient-Safety-Based

Interprofessional Collaboration Instructional Model for the Specialist-1 of Child Health Medical Education Program. 7(16), 134145.

Oneha, M. F., Yoshimoto, C. M., Bell, S., \& Enos, R. N. (2001). Educating health professionals in a community setting: What students value. Education for Health, 14(2), 256266.https://doi.org/10.1080/1357628 0110051091

Rasmita, Dina. (2018). Gambaran Persepsi Dan Kesiapan Mahasiswa Terhadap Implementasi Ipe (Interprofessional Education) Di Stikes Surya Global Yogyakarta. Jurnal Keperawatan Priority, Vol 1, No. 2, Juli 2018 ISSN 2614-4719, 1(2), 28-37.

Setyo, C., Sunartini, S., Retno, G., \& Kamasturyani, Y. (2018). National Cheng Kung University Hospital TAIWAN Conference Book International Conference on Health Care and Management. National 
Cheng Kung University Hospital TAIWAN Conference Book International Conference on Health Care and Management, ICMH 2018(138).

Sunguya, B. F., Hinthong, W., Jimba, M., \& Yasuoka, J. (2014). Interprofessional Education for Whom? - Challenges and Lessons Learned from Its Implementation in Developed Countries and Their Application to Developing Countries: A Systematic Review. 9(5).https://doi.org/10.1371/journal. pone.0096724

Tyastuti, D., Onishi, H., Ekayanti, F., \& Kitamura, K. (2013). An Educational Intervention of Interprofessional Learning in Community Based Health Care in Indonesia: What did We Learn from the Pilot Study? 4(25), 1-12.

Vrontos, E. B., Kuhn, C. H., \& Brittain, K. L. (2011). Impact of interprofessional activities on health professions students' knowledge of community pharmacists' role and services. American Journal of Pharmaceutical Education, 75(8). https://doi.org/10.5688/ajpe758152

WHO. (2010). Human Resources for Health Framework for Action on Interprofessional Education \& Collaborative Practice.

WHO. (2018). Patient safety: Global action on patient safety. $B M J$ Quality and Safety, 22(10), 809815. https://doi.org/10.1136/bmjqs2012-001748 